\section{THIRD INTERNATIONAL CONGRESS ON GLASS}

$\mathrm{T}$

HE Third International Congress on Glass was held in Venice during June 29-July 2, associated with the International Commission on Glass, the annual meeting of which was held on July 3. 179 delegates attended from twenty countries; they included 65 from Italy and 22 from Great Britain.

The Congress was organized by a Committee of the Italian Glass Manufacturers Federation. At the opening meeting of the Congress, Principe Giovanni Ginori Conti, who is president of the Federation, was inducted as president of the Congress by Dr. B. P. Dudding in his capacity as president of the Second International Congress on Glass held in London and Sheffield in 1936. This ceremony concluded with the presentation to Prince Ginori Conti by Mrs. W. E. S. Turner of a glass goblet on which the coat of arms of the Conti family had been engraved by Mrs. Turner, who is among the best of present-day English engravers.

The first day of the Congress was devoted to lectures on general subjects open to all members attending. Dr. M. Pasquato (Venice) reviewed the history of the glass industry centred in Murano since the eleventh century and traced the influence Venetian traditions have had on the artistic and industrial developments of the glass industry of the world. Prof. W. E. S. Turner (Sheffield) reviewed the growth of societies and research institutions not associated with specific industrial organizations since the formation of the Glass Research Delegacy in Sheffield in 1915 and the Society of Glass Technology in 1916. This was of particular interest to the Italian members, as negotiations have been proceeding between the Government and industry in Italy for some time, and a definite announcement was made at the end of the Congress reporting a decision to form both a technological society and in addition a research institute supported by government and industrial contributions. M. D'Argenlieu (Paris) reviewed the development of the use of glass in the building industry and raised some pertinent questions as to whether the glass industry had exhausted its contribution in this field. Prof. F. Roma (Bologna) described the sources of natural gas in northern Italy and discussed the conditions necessary to the efficient use in the glass industry. Prof. M. Czerny (Frankfurt am Main) indicated recent advances in the understanding of the problems of glass melting, and in particular the relative importance of heat transfer by radiation convection movements in the molten glass and conductivity through the glass. Mr. Edward Meigh (London) dealt with the interrelation of technology and management in modern industry, referring to the nature of the studies made in Great Britain under the auspices of the Institute of Industrial Administration and the British Institute of Management, with which the former is now amalgamated.

The following two days were devoted to specialized papers classified in four groups, three of which met simultaneously: Group I, Chemical and Physical Properties of Glasses ; Group II, Glass Manufacture : Materials, Equipment, Methods ; Group III, Form, Design, and Decoration of Glass ; Group IV, History and Archæology.

About fifty papers were presented, and their efficient discussion was secured by making arrange- ments under which delegates could hear the speaker in any one of four languages, by a miarophone and telephone service, which is becoming a general technique at international conferences.

In Group I several papers were presented which dealt with the modern physical concepts of the structure, and the slow changes which take place with time in the physical properties of glasses, depending on their previous thermal history. Another paper discussed the rate of reaction of glassforming materials and the influence of the particlesize and the scale of operations on the rate of reaction.

In Group II, important and novel ideas concerning the methods employed to melt glasses and the techniques for exploring new designs of glass-melting furnaces were presented and led to extended discussions.

The artistic and archæological interests of glass brought together artists from eight different countries, and in the course of the discussions the influence of the artist on production of utilitarian glassware was emphasized.

Associated with the Congress were visits to Soc. Venez. Conterie e Cristallerie, Murano, to Vetrocoke at Porto Marghera, together with visits to museums, the Giorgio Cini Foundation on the isle of S. Giorgio Maggiore, and to the hydro-electric plant at Caverna, owned by the Società Adriatica di Elettricità. The Congress closed with a banquet at the Excelsior Palace at the Lido, given by the Associazione Nazionale degli Industriali del Vetro.

At the annual meeting of the International Commission on Glass held on July 3, Dr. B. P. Dudding, honorary secretary of the Commission, was elected president in succession to Prof. W. E. S. Turner, who has been president of the Commission since its formation in 1933. Prof. Turner was elected honorary president of the Commission. M. H. Vandecapelle, director of the Institut National du Verre, Belgium, was elected honorary secretary, and M.- G. Henry, director general of the Union des Verreries Mécaniques, Belges, was elected honorary treasurer on the resignation of Dr. W. M. Hampton, of Chance Brothers, Ltd., Birmingham.

A tentative invitation was extended by the Swedish delegate to the Commission to hold its annual meeting in Sweden in 1954. No decision was taken in respect of the next Congress; but it is hoped that it will be held on the Continent in 1956.

\section{ADVANCES IN METHODS OF STUDYING CLAYS}

A MEETING of the Clay Minerals Group of the Mineralogical Society, held in the Department of Geology and Mineralogy, Marischal College, Aberdeen, during April 10-11, was mainly devoted to a discussion upon advances in methods of studying
clays. On the morning of April 10, the laboratories of the Macaulay Institute for Soil Research and the Chemistry Department of the University were visited by members of the Group. At the scientific sessions the chair was occupied on the afternoon of April 10 by Dr. G. W. Brindley (University of Leeds) and on the following morning by R. H. S. Robertson (Glasgow).

Introducing the discussion, Dr. G. Nagelschmidt (Safety in Mines Establishment, Sheffield) reviewed 